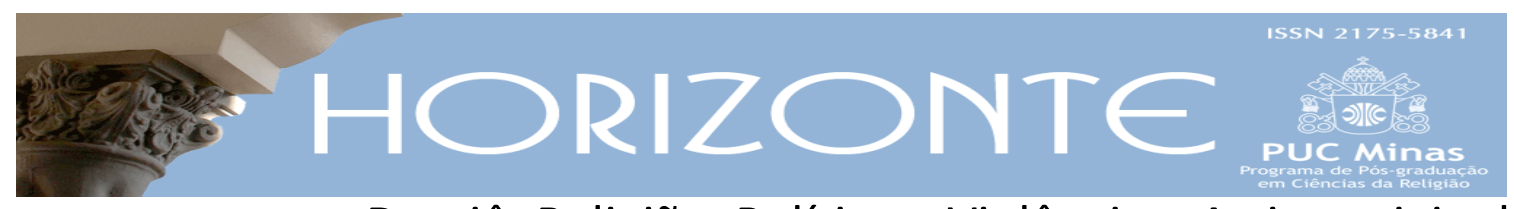

Dossiê: Religião, Política e Violência - Artigo original (c) $)(9 \Theta$

\title{
Religião politizada contra violência institucionalizada: a Teologia da Libertação no imaginário religioso mundial Politicized religion against institutionalized violence: Liberation theology in the global religious imaginary
}

Alberto da Silva Moreira *

\begin{abstract}
Resumo
Desde seus inícios no final dos anos 60 na América Latina, a Teologia da Libertação, tanto como movimento social-político-religioso como reflexão teórica, influenciou igrejas, comunidades religiosas, grupos politicamente engajados, movimentos sociais de base religiosa, étnica, nacionalista e de gênero em muitas partes do mundo. Essa teologia, para enfrentar as muitas formas institucionalizadas da violência (fome, exclusão social, preconceito de gênero, classe, etnia), levou a sério a política como mediação para a fé. Num longo processo de diferenciação interna e de abertura temática e metodológica, em que não faltaram crises e conflitos, as diversas teologias da libertação interagiram com outras teologias, religiões e culturas. Hoje, devido ao processo de globalização cultural, está emergindo um imaginário social e religioso global. As teologias da libertação (na forma de relatos, biografias, símbolos, imagens, motivos, hermenêutica de textos sagrados e métodos de organização popular) se globalizaram e estão contribuindo para formar um imaginário social em torno da religião. Neste imaginário um aspecto da TdL que sobressai é justamente este: uma fé religiosa que assume responsabilidade política diante das formas estruturais de violência. Tal imaginário, mesmo se aparentemente intangível, influencia as práticas e o próprio horizonte da percepção da realidade, na religião e na política.
\end{abstract}

Palavras-chave: Teologia da libertação; Religião; Política; Globalização; Imaginário religioso

\begin{abstract}
Since its beginnings, in the late 60 's in Latin America, liberation theology, both as a social-political-religious movement as a theoretical reflection, influenced churches, religious communities, political engaged groups, faith, ethnic, nationalist and gender-based social movements in many parts of the world. This theology, in order to face the many institutionalized forms of violence (hunger, social exclusion, gender, class and ethnic prejudices) took politics seriously as mediation to religious faith. During a long process of internal differentiation and opening to new themes and methods, in which there were many crises and conflicts, the various liberation theologies interacted with other theologies, religions and cultures. Today, due to the cultural globalization processes, a social and religious global imaginary is on the rise. Theologies of liberation (in the form of reports, biographies, symbols, images, motifs, hermeneutics of sacred texts and methods of popular organization) are globalized and are contributing to form a social imaginary around religion. In this imaginary one aspect of liberation theology that emerges is precisely that of a religious faith which assumes political responsibility before structural forms of violence. Such imaginary, even if seemingly intangible, it has influenced the practices and the actual horizon of reality perception in religion and in politics.
\end{abstract}

Keywords: Liberation theology; Religion; Politics; Religious imaginary; Globalization

Artigo recebido em 20 de novembro de 2013 e aprovado em 09 de Março de 2014.

* Doutor em Katholische Theologie. Professor da Universidade Católica de Goiás no Programa de Pós-Graduação Stricto Sensu em Ciências da Religião. País de origem: Brasil. E-mail: alberto-moreira@uol.com.br.

Horizonte, Belo Horizonte, v. 12, n. 33, p. 12-42, jan./mar. 2014 - ISSN 2175-5841 


\section{Introdução}

Desde seus inícios no final dos anos de 1960 na América Latina, muitas ideias-chave da Teologia da Libertação, entendida como movimento socialpolítico-religioso, influenciaram igrejas e comunidades religiosas, movimentos políticos e sociais de base religiosa, étnica, nacionalista e de gênero em muitas partes do mundo. Diversos grupos políticos, movimentos sociais e ONGs que lutaram e lutam contra formas institucionalizadas de violência (exploração econômica, violação dos direitos humanos, marginalização cultural, opressão étnica e de gênero, predação ambiental), sentem-se ligados ao ideário da(s) Teologia(s) da Libertação.

Essa expansão e recepção cultural, política e religiosa permitem falar de uma presença influente da Teologia da Libertação no imaginário religioso global. Tal imaginário vai se constituindo pelo fluxo global de pessoas, tradições, ideias e representações religiosas, plataformas políticas, imagens de lutas sociais e de mobilização baseadas na religião. Este artigo, que se situa na perspectiva das ciências da religião, pretende mostrar que as teologias da libertação contribuem para formar um imaginário social em torno da religião; nesse imaginário a religião é percebida como crítica social e prática política contra formas institucionalizadas de opressão e violência. Tal percepção choca-se contra o projeto conservador e despolitizador do cristianismo, que o reduz à satisfação das necessidades subjetivas individuais. Tentarei, em primeiro lugar, elaborar uma compreensão da Teologia da Libertação que faça justiça à sua diversidade interna de lutas, grupos e orientações teóricas. Isso só pode ser feito numa recorrência constante à história desse movimento. Em segundo lugar procurarei refazer o processo de transnacionalização da(s) Teologia(s) da Libertação, e abordar as consequências que isso trouxe para essa teologia. Em terceiro lugar proponho uma noção de imaginário religioso que capte no âmbito da cultura global em formação, as representações e ideias-força das Teologias da Libertação. 


\section{As Teologias da Libertação - traços mínimos de um perfil}

Ao utilizar a expressão "Teologia da Libertação"1 no singular (doravante abreviada por TdL), estou me referindo primeiramente ao movimento religioso, social e político surgido na América Latina nos anos de 1960 e 70, do qual continuam participando, ainda que em número muito menor, milhares de militantes leigos, bispos, padres e pastores. Em segundo lugar, estou me referindo também à produção teológica, expressão teórica desse movimento, sistematizada pelos teólogos e pelas teólogas da libertação. A expressão Teologia da Libertação certamente engloba muitas outras teologias libertadoras além da teologia latinoamericana, mas quando for o caso farei uma referência específica. O movimento e a teoria que ele continua produzindo são duas faces da mesma realidade, eles se interpenetram e se reforçam mutuamente. Este movimento histórico incluiu amplos setores da Igreja Católica na América Latina e em menor medida também setores das igrejas protestantes, e mesmo pessoas sem uma clara filiação confessional. Por isso Michel Löwy o denominou inicialmente "Catolicismo radicalizado" (1989) e mais tarde "Cristianismo de Libertação" (2000), para distingui-lo de outras formas, tradicionais ou conservadoras, de cristianismo.

Diversas periodizações têm sido propostas para entender o surgimento e a propagação da teologia da libertação (DUSSEL, 1995; COMBLIN, 2000; SEGATO, 2006). Um desafio é explicar como foi possível surgir tal teologia, ligada a um ideário de protesto, defensora de mudanças radicais e criadora de instâncias críticas e participativas, como pastorais sociais e Comunidades de Base, a partir de estruturas eclesiásticas autoritárias, conservadoras e apoiadoras do status quo, como eram principalmente a Igreja Católica, mas também algumas igrejas protestantes na América Latina. Outro desafio é entender como essa teologia contextual, profundamente enraizada na história e nas condições sócio-culturais da

\footnotetext{
${ }^{1}$ Em seus próprios termos, a teologia latino-americana da libertação se considera um movimento que busca viver a fé (cristã) como práxis de libertação do ser humano de todas as formas de opressão e sofrimento, começando pela solidariedade com os pobres e pela denúncia dos sistemas idolátricos que os sacrificam, para incluir as vítimas de todas as formas de injustiça, preconceito e exclusão, até assumir a causa da própria natureza e do planeta terra. Esta práxis de libertação une, sem reduzir uma à outra, redenção espiritual com libertação na história, seja na economia, na cultura, na política ou nas relações de gênero; para isso ela exige um novo horizonte hermenêutico, uma mudança de lugar social e uma espiritualidade libertadora (jesuânica, bíblica, feminista, holística, afinal interreligiosa), a serem cultivadas através de formas igualitárias e participativas de vida em comum.
} 
América Latina, pôde ser entendida, decodificada e refundida em contextos sócioculturais distantes e muito diferentes. Houve fatores internos e externos à TdL que favoreceram tanto uma coisa como a outra. Para os propósitos deste artigo seja permitido fazer referência apenas aos momentos e aspectos mais importantes do processo.

A fase preparatória da teologia da libertação, ainda dentro dos paradigmas e na dependência da teologia européia tradicional, tem início nos anos de 1950 e no começo dos anos 60 na Europa, na América Latina e no Brasil. Nesse período são criadas algumas condições necessárias e uma rede de contatos que mais tarde possibilitaram a articulação continental da TdL. No campo católicoromano, algumas dessas pré-condições podem ser assim resumidas: fundação da CNBB (1952), do CELAM (1955) e da CLAR-Conferência Latino-Americana de Religiosos-CLAR (1958); engajamento social dos leigos através dos vários organismos da Ação Católica (JUC, JOC, JEC e ACO); atuação dos padres operários e dos membros da fraternidade de Charles de Foucauld, que trabalham em fábricas e vivem nas periferias uma espiritualidade da pobreza; formação de muitos padres, teólogos e cientistas sociais latino-americanos no espírito crítico das universidades de Lovaina e Paris; o papado de João XXIII e suas encíclicas sociais (Mater et Magistra e Pacem in Terris); a aproximação ou confronto produtivo que a militância estudantil e operária católica (em alguns casos também protestante) estabelece com os grupos de esquerda e com o marxismo²; o envolvimento sempre maior da Igreja Católica brasileira, temerosa do comunismo, com a fundação de sindicatos de trabalhadores rurais e com a luta pela terra no interior do Brasil; a criação do Movimento de Educação de Base-MEB (março de 1961), da pastoral radiofônica e das primeiras comunidades de base na zona rural das dioceses de Volta Redonda e Natal (1960-1961). Outros acontecimentos mais amplos marcam os horizontes da época, como a Guerra Fria, a revolução cubana, as propostas desenvolvimentistas da Comissão Econômica para a América Latina (Cepal) e um

\footnotetext{
2 "Podemos datar o nascimento dessa corrente, que poderíamos denominar como "cristianismo da libertação" no começo dos anos 60 , quando a Juventude Universitária Católica brasileira (JUC), alimentada pela cultura católica francesa progressista (Emmanuel Mounier e a revista Esprit, o padre Lebret e o movimento "Economia y Humanismo", o Karl Marx do jesuíta J.Y. Calvez), formula por primeira vez, em nome do cristianismo, uma proposta radical de transformação social (LÖWY, 2008, p.1)
} 
clamor generalizado na América Latina por reformas de base e contra o imperialismo.

A fase seguinte é a fase do nascimento da teologia da libertação latinoamericana (1965-1972) que começa, na minha opinião, no último ano do próprio Concílio Vaticano II (1965). Com efeito, a questão central para a TdL é a opção pelos pobres, e esta não foi tomada primeiro em Medellín (1968), mas já em 1965, no final do Concílio pelo grupo de 40 bispos que assinou o impressionante Pacto das Catacumbas (BEOZZO, 2009; BETAZZI, 2012).3 Neste encontro e no documento que ele produziu, para os quais foi fundamental a liderança carismática e profética de D. Hélder Câmara, está proposto, com todas as letras, o compromisso de viver pobre e trabalhar com os pobres. Aliás, o estudo de cartas e fontes históricas mostrou que D. Hélder Câmara foi uma figura de fundamental importância para o surgimento da Teologia da Libertação.4

Esta fase do nascimento da TdL envolveu ainda, do lado protestante, a importante Conferência do Nordeste, em julho de 1962 (CONFEDERAÇÃO, s/d), o instituto ISAL (Iglesia y Sociedad en América Latina) e os nomes de Richard Shaull, prebiteriano norte-americano que viveu na Colômbia e no Brasil, José Míguez Bonino, metodista argentino, Rubem Alves, presbiteriano brasileiro e Sergio Arce Martínez, presbiteriano cubano (SEGATO, 2006). A princípio não houve muito contato entre pensadores protestantes e católicos, os grupos surgiram de forma praticamente paralela; mas a partir de 1970 o intercâmbio foi constante. No lado católico se destacam o peruano Gustavo Gutiérrez, o brasileiro Hugo Assmann, o uruguaio Juan Luís Segundo e o argentino Enrique Dussel. O primeiro trouxe a perspectiva da espiritualidade e da força dos pobres, o segundo a crítica

\footnotetext{
${ }^{3}$ Este foi o nome pelo qual ficou conhecido um pacto firmado em 16 de novembro de 1965, três semanas antes do final do Concílio Vaticano II, nas catacumbas de Domitila em Roma, por 39 padres conciliares de diferentes países, integrantes do grupo "igreja dos pobres". Nesse pacto, só divulgado tempos depois, os bispos renunciavam a toda forma de pompa, riqueza e exercício arbitrário do poder e se dispunham a colocar os pobres no centro da sua atuação pastoral. Segundo J. Beozzo (2009), entre os bispos que firmaram o documento ou participavam do grupo estavam Hélder Câmara, José Maria Pires, Antonio Fragoso, João B. Mota, Cândido Padim; Leonidas Proaño (Equador), Manoel Larraín (Chile), entre outros. (Concilium, v. 13, n. 124(4), 1977; BETAZZI, 2012).

${ }^{4}$ Além de pastor dos pobres, D. Hélder atuou incansavelmente como intelectual, redator, negociador, articulador de uma rede de contatos e difusor internacional das causas da teologia da libertação. Depois do Concilio ele participou na organização de uma série de encontros teológicos e na elaboração do texto-base (encomendado a José Comblin) da conferência de Medellín.
} 
mordaz ao capitalismo, o terceiro insistiu na mudança da própria teologia (COMBLIN, 2000, p. 185), o quarto introduziu a perspectiva histórica e fez a conexão com o passado latino-americano. A teologia latino-americana da libertação nasce, portanto, internacional, interdisciplinar e ecumênica.

O grande acontecimento que por breves anos galvanizou a Igreja Católica no continente, o suficiente para dar legitimação e impulso à formulação e à difusão da Teologia da Libertação, foi mesmo a III Assembléia Geral dos Bispos em Medellín, de 24 de agosto a 6 de setembro de 1968. Nesse encontro, feito para aplicar o Concílio à realidade latino-americana, o episcopado analisa e denuncia a injustiça social, a extrema pobreza e marginalização vividos pela maior parte da população, sobretudo a juventude. A opção pastoral pelos empobrecidos do continente é clara. Infelizmente, os indígenas e as mulheres ficaram praticamente de fora do documento final (SUESS, 2009, p. 28). Onze anos mais tarde, em Puebla, já sob o pontificado de João Paulo II, somente a custo o episcopado conseguiu reafirmar essa linha pastoral e teológica libertadora.

O encontro de Medellín, junto com os documentos que produziu, tornou-se um "evento epocal", quase um mito de origem, sempre de novo mencionado no imaginário em torno da Teologia da Libertação. Sob muitos aspectos aquele ano de 1968 foi emblemático para a teologia, no Brasil e no mundo (FÜSSEL; RAMMINGER, 2009; VENTURA, 1985; MOREIRA, 2009). Apesar da ditadura militar no Brasil, reinava em muitos círculos da igreja e da esquerda latinoamericana um grande otimismo. Como disse Comblin (2000, p. 180), "foi a época da utopia. Impôs-se a ideia de que tudo era possível... Bastava querer para transformar a sociedade capitalista em uma sociedade socialista.” Teoricamente respaldados pelas análises da Teoria da Dependência e politicamente motivados pelo exemplo cubano, muitos acreditavam que uma revolução era possível e que profundas mudanças sociais e econômicas iriam acontecer.

$\mathrm{Na}$ ambiência dessa convicção aparecem as primeiras obras que trazem explicitamente o nome de Teologia da Libertação: a tese de Rubem Alves em 
Princeton, Towards a Theology of Liberation, em 1968; Teología de la Liberación, de Gustavo Gutiérrez em 1971, aproximando cristianismo e socialismo; Caminos de Liberación Latinoamericana, de Enrique Dussell em 1972. O livro de Gutiérrez por sua densa e sistemática elaboração das questões centrais, e ainda pela grande repercussão que recebeu, é logo assumido como a obra fundadora da Teologia da Libertação.

A terceira fase (1973-1989) foi de expansão e crescimento da Teologia da Libertação, consolidando um perfil e uma agenda própria na teologia mundial. Esse período também foi marcado pela defensiva e, afinal, pela condenação por parte da hierarquia católica. Explico minha opção por essa datação: neste período além da expansão houve uma perseguição interna e externa contra a TdL. Mesmo assim, considero que tanto a agenda política da Teologia da Libertação, como movimento religioso e social, como o paradigma epistemológico dominante na reflexão teológica (centralidade do pobre, reino de Deus e história, orthopraxis, hermenêutica bíblica e sociedade atual), não se alteraram substancialmente até o final dos anos 80. Mesmo com a revalorização da religiosidade popular em meados dos anos 70, esta "plataforma" da TdL gozava de aceitação e conferia identidade e plausibilidade interna e externa ao movimento. Não quero dizer que já não existissem posições teóricas críticas ou mesmo propostas mais exigentes e diferenciadas dentro da Teologia da Libertação, sobretudo por parte das teólogas feministas (GEBARA, 2006; RUETHER, 2000; AQUINO, 1992) e dos poucos que pensavam uma teologia indígena (GIACCARIA, 1990). Mas essas críticas e propostas não encontravam eco na maioria dos teólogos masculinos da libertação, ainda um tanto machistas e eclesio-centrados para questionar o próprio paradigma epistemológico da TdL. Além disso, no final dos anos 80, a TdL foi obrigada a reunir suas forças para enfrentar inimigos poderosos: do lado externo, a opressão econômica imposta pelo neoliberalismo, ainda mais brutal do que no período anterior, conjugada com a repressão policial-militar e dos latifundiários, que deixava inúmeras vítimas; do lado interno, a perseguição por parte dos conservadores e do Vaticano exigia uma constante auto-justificação e uma firmeza nas “questões centrais". Nesse período de consolidação e expansão, de 1973 a 1989, 
além dos nomes já citados, muitos outros teólogos e teólogas deram uma contribuição essencial à Teologia da Libertação, impossível de ser sumarizada neste espaço. 5

Nessa época há uma enorme produção teológica e pastoral, publica-se uma quantidade impressionante de livros, revistas, panfletos, cartilhas e material didático, em boa parte para subsidiar o trabalho das nascentes comunidades de base, dos grupos bíblicos e das pastorais sociais. Institutos de teologia e pastoral são fundados ou recebem uma nova orientação; milhares de cursos, programas de formação, encontros, semanas de estudos e workshops de todos os tipos acontecem pelo continente; teólogos e lideranças leigas, indígenas e operárias de muitos países da América Latina se encontram pela primeira vez. Nesses encontros se perfila e se elabora um perfil teológico próprio. Dos colóquios e seminários dos teólogos surgem as associações regionais, nacionais e continentais de teologia.

Entre os numerosos encontros, um dos mais importantes e programáticos foi o de El Escorial, em julho de 1972, em Madrid (INSTITUTO, 1977). Também em 1972 acontece no Chile o primeiro congresso do movimento Cristãos para o Socialismo (CPS). O intento fundamental do CPS era colocar em evidência que a fé e a luta pela justiça dos partidos de esquerda podem ser assumidas pelos cristãos, superando velhos dogmas de exclusão mútua, tanto por parte da Igreja como dos partidos comunistas (JAUME, 2009). Rapidamente Cristãos para o Socialismo se espalhou por toda a Europa. Mesmo sem representar em senso estrito a teologia da libertação, o CPS aparece como sua ponta avançada (COMBLIN, 2000, p. 185).

Na mesma década de 1970, no auge da ditadura militar e da violência contra índios e posseiros, criam-se as importantes pastorais sociais da igreja católica no Brasil, como o Conselho Indigenista Missionário (CIMI) em 1972, e a Comissão Pastoral da Terra em 1975 (CPT, 1985; POLETTO; CANUTTO, 2002; MOREIRA,

\footnotetext{
${ }^{5}$ Lembro apenas alguns: Leonardo e Clodovis Boff, Carlos Mesters, José Comblin, J.B. Libanio, Franz Hinkelammert, Pablo Richard, Ivone Gebara, Ronaldo Muñoz, Elza Tamez, Sergio Torres, Tamayo Acosta, Míguez Bonino, Segundo Galilea, Juan C. Scannone, Jon Sobrino, Ignacio Ellacuría, Maria Pilar Aquino, Gonzalo Arroyo. No período seguinte essa menção, pela quantidade, se torna impossível.
} 
2006), estreitamente vinculadas à teologia da libertação. Aliás, nessa época é intensa e explícita a vinculação da teologia da libertação com os movimentos sociais e políticos que lutam na América Latina por democracia e direitos políticos, pela terra e por moradia nas cidades, por direitos humanos, indígenas e sociais (SCHERER-WARREN, 1996; MOREIRA, 2012). Há uma intensiva formação de quadros e lideranças que anos depois irão engrossar os partidos políticos de esquerda, os sindicatos e iniciativas pela cidadania, ou que atuarão em processos revolucionários, como na revolução sandinista na Nicarágua (1979) e no levante popular contra a violência brutal das oligarquias em El Salvador (de 1977 até 1992). Em diversos países, a confiança ingênua da Teologia da Libertação no papel messiânico dos pobres ou na própria Igreja sofre outro duro golpe: com a retomada do processo democrático as classes populares elegem candidatos de direita, e a Igreja impõe a Boff e depois a Ivone Gebara anos de silêncio. Mesmo assim, a contribuição histórica da Teologia da Libertação, através das suas publicações, cursos, materiais, comunidades de base e pastorais sociais, foi decisiva para ajudar a criar uma nova cultura política na América Latina e no Brasil. Houve, em intensidades distintas segundo os países, um amplo processo de reeducação popular, voltado à participação e à luta pela cidadania.

Para Segato (2006), a propagação através de países periféricos a partir dos anos 70 levou a um estágio de globalização da Teologia da Libertação, como veremos no próximo item. Mas essa expansão também coincidiu com a perseguição e o assassinato de muitas das suas lideranças pelos regimes militares e pelos latifundiários: o bispo Angelelli na Argentina; Mons. Romero em El Salvador, o teólogo Ignacio Ellacuría e outros jesuítas, também em El Salvador; no Brasil, o Pe. Penido Burnier, o líder sindical Santo Dias da Silva em São Paulo, o padre Josimo M. Tavares no Maranhão. Dentro da própria Igreja, a ofensiva da ala conservadora já havia começado em 1972, liderada pelo cardeal Alfonso López Trujillo, presidente do CELAM, pelo cardeal Scherer de Porto Alegre e o cardeal Eugênio Sales do Rio de Janeiro. 6 No Vaticano desponta a figura do Cardeal Ratzinger,

\footnotetext{
6 “Na América Latina, a grande virada foi o golpe de Sucre, em 1972, que entregou o CELAM a Alfonso Lopez Trujillo." (Comblin, 2000, p. 183).
} 
nomeado em 1981 para a Congregação para a Doutrina da Fé. Ele edita em agosto de 1984 uma Instrução sobre Alguns Aspectos da Teologia da Libertação, criticando-a fortemente e causando uma enorme repercussão (IGREJA CATÓLICA, 1984). Uma segunda Instructio, Sobre a Liberdade Cristã e a Libertação, dessa vez mais diferenciada e positiva, ligando a liberdade com o Evangelho, foi editada em 22 de março de 1986 (IGREJA CATÓLICA, 1986). Três semanas depois, em carta à CNBB, João Paulo II modera sua antipatia contra a TdL, ao afirmar que "na medida em que se empenha por encontrar aquelas respostas justas (...), a teologia da libertação é não só oportuna, mas útil e necessária". Apesar disso, ao longo de toda a década e nos anos que se seguiram, a campanha interna do Vaticano contra a TdL e seus porta-vozes em nada diminuiu - como cena paradigmática ficou o dedo em riste de João Paulo II apontado para Ernesto Cardenal no aeroporto de Manágua em 1983 (MOREIRA, 2011).

No final dos anos 80, a teologia latino-americana da libertação está madura e faz suas sínteses teológicas: Leonardo Boff organiza a publicação da série Teologia da Libertação, Ignacio Ellacuría, Jon Sobrino e outros publicam em 1990 o compêndio Mysterium Liberationis. Tanto o recorte hermenêutico da TdL como a pauta de ação que dele decorre vão se alterar fortemente a partir dos anos 90, com o fim do socialismo e a redemocratização. Nessa situação diferenciada criaram-se condições para que as críticas das teólogas feministas da libertação, como Ivone Gebara, Elza Tamez e Pilar Aquino, e os reclamos dos teólogos indígenas, como Aiban Wagua, encontrassem maior ressonância. Foi também nesse contexto que Leonardo Boff (1992a; 1992b; 1992c; 1993a e 1993b) pode plantear a introdução do paradigma ecológico na forma de pensar a teologia da libertação.7

Um quarto período da Teologia da Libertação, que vem dos anos 1990 até os nossos dias, pode ser chamado de fase das releituras, mas também de fase da fragmentação e da diferenciação interna. Num contexto eclesial já controlado

\footnotetext{
${ }^{7}$ Segundo Comblin, “Até 1990 a teologia da libertação ainda tinha capacidade para pensar em síntese” (2000, p. 186)
} 
pela Cúria romana, muitos teólogos se dedicam a fazer retrospectivas e a analisar (auto)criticamente a história já vivida pela Teologia da Libertação (BOFF, 1996; SUSIN, 2000; RIBEIRO, 2010). Entre essas críticas, percebeu-se que não houve um enfrentamento ou diálogo produtivo com o movimento evangélico pentecostal; que foi negligenciado pela TdL um engajamento pela melhoria e cumprimento das leis, pois elas eram a garantia dos direitos duramente conquistados; que a mudança do cenário político não foi acompanhada por um agenda propositiva; que um certo horizonte messiânico do tudo ou nada dificultou o envolvimento direto na busca de alternativas concretas para os problemas; que aspectos importantes como a sexualidade e a prazeirosidade da vida (ASSMANN, 1994) às vezes foram relegados a segundo plano; que faltava ainda integrar uma teologia gay à TdB. Enfim, que continua faltando às Teologias da Libertação um "projeto histórico" comum (von SINNER, 2009, p. 125).

No mesmo período, as diversas correntes e orientações internas forçam a Teologia latino-americana da Libertação a abrir-se de forma mais corajosa à pluralidade teórico-metodológica. O esforço de autocrítica levou a um vivo debate e à inclusão de outros grandes campos ou tarefas para as teologias da libertação: a Ecoteologia proposta por L. Boff (1992; 1993a; 1993b), que assumiu de maneira consequente e corajosa a crise ambiental planetária; a Teologia Índia, ${ }^{8}$ que se articulou na América Latina, "na mesma medida em que os povos indígenas cresceram em seus ganhos políticos, no reconhecimento de seus espaços culturais e, inclusive, religiosos" (SUSIN, 2009); a Teologia Afro-descendente que se fortaleceu e se articulou melhor com a TdL (ATABAQUE, 1997), e a Teologia do Pluralismo Religioso, que impactou positivamente a TdL, sobretudo em seus pressupostos cristãos (QUEIRUGA, 1996; ASETT, 2003; VIGIL, 2006; RIBEIRO, 2013). Neste período acentua-se a transferência, mais ou menos compulsória, de um bom número de teólogos, teólogas e agentes pastorais, tanto leigos como ex-

\footnotetext{
${ }^{8}$ A Teologia Índia é fruto amadurecido de uma longa caminhada por dentro da Teologia da Libertação (WAGUA, 1992; SUESS, 2007); talvez por isso ela tem recebido, sobretudo no México, desconfiança e intimidação por parte de setores conservadores da hierarquia católica. Ela e a Teologia Índia tendem a se tornar "teologias de diálogo entre as formas tradicionais, ancestrais e a forma cristã de expressão religiosa e teológica" (SUSIN, 2009).
} 
religiosas ou ex-sacerdotes, para a área acadêmica e para outras profissões. Isso provoca uma perda de quadros envolvidos diretamente com as comunidades e os movimentos sociais. Por outro lado aumentam exponencialmente os contatos e parcerias internacionais, os estudos e a produção teórica sobre aspectos da Teologia da Libertação. Um processo político e revolucionário de grande repercussão mundial, ligado à $\mathrm{TdL}$, foi a revolta zapatista em Chiapas, no México, em janeiro de 1994. Conforme avançaram os processos de globalização, avançaram também as articulações da TdL com os movimentos sociais internacionais, o movimento altermundista e os grupos envolvidos no diálogo inter-religioso (TOMITA; BARROS; VIGIL, 2005, 2006 e 2008). A partir de 2005 organiza-se um Forum Mundial de Teologia da Libertação, articulado com o Forum Social Mundial, que naquele ano aconteceu em Porto Alegre. Adiante voltarei ao tema. Em outubro de 2012 diversas entidades coordenadas por Ameríndia realizaram na Unisinos, na região metropolitana de Porto Alegre, um histórico Congresso Continental de Teologia, para celebrar os 50 anos do Concílio e 40 anos de Teologia da Libertação. O congresso, que foi antecedido por jornadas regionais em todo o continente, permitiu o encontro de diferentes gerações, línguas e culturas dentro da TdL, além de gerar grande volume de material relevante (BRIGHENTI; HERMANO, 2013; IHU, 2012)

\section{A transnacionalização da Teologia da Libertação}

Como se deu o processo de transnacionalização? O que se globaliza da TdL?

É fato que na mesma época do surgimento da teologia latino-americana da libertação, nos anos 60, articulavam-se outras formas de teologia libertária nos Estados Unidos, como a teologia negra e a teologia feminista. No entanto, o que deu nome, identidade e ressonância a essa teologia no mundo inteiro, foi o processo sócio-político concreto da luta contra a pobreza econômica, a marginalização cultural, a exclusão política e a violência contra os direitos humanos na América Latina, inclusive pelo grande número de mártires que exigiu. 
Esse longo processo, vivido e elaborado pelos teólogos vinculados à Teologia da Libertação até o presente, é chamado de "caminhada de libertação". Os teólogos latino-americanos, por causa das ditaduras e do Appartheid social continuaram insistindo no conceito central do "pobre" e no aspecto econômico-político do seu processo de (auto)libertação; mas não se fecharam; buscaram apoio e diálogo com outras teologias libertárias, como a teologia negra de James Cone, a teologia feminista norte-americana, a teologia dos chicanos, dos povos nativos norteamericanos e com a teologia europeia mais avançada da época, como a teologia política de J.B. Metz, a teologia da esperança de J. Moltmann, a ética teológica de Hans Küng e de Norbert Greinacher. O meio privilegiado para que essas trocas acontecessem foram os encontros e os congressos de teologia. Um encontro onde aconteceram debates acalorados e "polinizações mútuas", com consequências futuras para o debate entre as diferentes modalidades de teologia da libertação, foi a conferência "Theology in the Americas" (TORRES; EAGLESON, 1976), realizada em Detroit em agosto de 1975 e da qual participaram J. Cone, H. Assmann, L. Boff, Rosemary Ruether, G. Gutiérrez, Juan L. Segundo, G. Baum, A. Dulles, José M. Bonino, E. Dussel, D. Roberts, Monika Hellwig e outras teólogas e teólogos.

Nos encontros internacionais surgiram as entidades representativas da nova plataforma teológica. Assim, durante a conferência Ecumenical Dialogue of Third World Theologies, em 1976 em Dar-es Salam, que reuniu 22 teólogos da África, Ásia e América Latina, foi fundada a Associação Ecumênica de Teólogos e Teólogas do Terceiro Mundo (ASETT ou EATWOT em inglês) (TORRES; FABELLA, 1978). Depois dessa conferência, que marca o início da entidade, EATWOT organizou muitos outros encontros de teólogos do Terceiro Mundo: em 1977, uma conferência dos teólogos africanos em Accra, Gana (APPIAH-KUBI; TORRES, 1979); em 1979 uma conferência dos teólogos asiáticos em Wennappuwa, no Sri Lanka (SEGATO, 2006); em 1980 uma conferência latino-americana em São Paulo. Desde essa época a ASETT e as associações de teólogos e teólogas de cada continente (na América Latina a Comissão Teológica Latino-americana) e mesmo dos países (no Brasil a SOTER) têm sido uma instância importante na tarefa de realimentar e reciclar as diferentes correntes dentro da Teologia da Libertação. 
Outra instituição que tem dado uma importante contribuição ao processo de globalização da Teologia da Libertação é o Conselho Mundial de Igrejas (WCC) que desde os anos 70 leva os anseios centrais dessa teologia às igrejas cristãs afiliadas em todo o mundo. A última iniciativa de grande importância no processo de transnacionalização da Teologia da Libertação surgiu em 2005, na esteira do Forum Social Mundial: o Forum Mundial de Teologia e Libertação. Este eventoprocesso que reúne centenas de teólogas e teólogos identificados com as mais diversas causas libertárias, já teve cinco edições mundiais, sempre em países do Terceiro Mundo. Ele oferece um espaço para o diálogo entre os vários discursos teológicos, visibiliza os grupos e faz a conexão da teologia com os contextos e as lutas locais por libertação. Tornou-se um referencial global para as teologias da libertação e seus anseios por um mundo diferente (SUSIN, 2009).

Nos inícios dos anos 70, a TdL começa a ser recebida internacionalmente e alcança a África e Ásia. Na África, num clima de debate, controvérsia e às vezes rejeição, os teólogos que mais interagiram com a TdL formaram três grupos: 1) aqueles engajados na luta anti-Appartheid na África do Sul (BUTHELEZI; BIKO; PITYANE, 1972), alguns deles defendendo uma ligação apenas com a Teologia Negra de James Cone; 2) os defensores de uma Teologia Africana, a teologia da inculturação (DICKSON; ELLINGWORTH,1969); e 3) os que propriamente propunham uma Teologia africana da Libertação (NTHAMBURI, 1980; UKPONG, 1984; MUZOREWA, 1989). O debate entre essas linhas ainda continua; ele recebeu a seguir a contribuição crítica das teólogas africanas feministas da libertação (ACKERMANN, 1988; ODUYOYE, 2001) e ultimamente agregou-se a ele o paradigma da reconstrução, defendido por J. Mugambi. Para Mugambi este século deve ser o da reconstrução, da cura das grandes feridas deixadas pelo Appartheid e da colocação de novos fundamentos na teologia africana (MARTEY, 2007, p. 87).

Também em regiões mais pobres e conflitivas da Europa, como na Andalusia, no sul da Espanha, e até certo ponto na Irlanda (McDONNAGH, 1977), houve uma recepção relativamente rápida da Teologia da Libertação nos anos 70. 
Na Ásia a Teologia da Libertação também chegou no começo dos anos 1970 e desde então a maioria das teologias asiáticas, até mesmo as teologias não-cristãs, estabeleceram com ela um diálogo estreito e criativo. A Ásia se caracteriza, segundo a expressão de Aloysius Pieris, por ser um continente massivamente pobre e massivamente religioso. Nele a recepção da Teologia da Libertação se fez e está se fazendo segundo as características, a mundividência e a gramática das culturas locais. Há diversas situações semelhantes às enfrentadas pela TdL latinoamericana, como o enorme abismo entre ricos e pobres, o passado colonial, a pobreza e exclusão das massas, o patriarcado opressor e controlador da mulher (CHAKKALAKAL, 2001), a exploração das crianças, a corrupção no sistema político, etc. Por outro lado, a visão de mundo, os valores e a forma de pensar estão profundamente enraizados numa visão cósmica e religiosa da realidade. A Ásia é o berço das grandes religiões do mundo, ela pode, mais do que ninguém, "beber do seu próprio poço”. Não se trata, portanto, de adaptações ou empréstimos, mas de uma recriação da $\mathrm{TdL}$ segundo o contexto asiático. As experiências mais conhecidas de recepção e influência da Teologia da Libertação na Ásia são aquelas realizadas pelo movimento Mingjung na Coréia, pela Teologia da Luta nas Filipinas, pela Teologia Dalith na Índia e pela Teologia Feminista asiática.

a) Os teólogos inseridos no movimento popular Minjung lutavam por justiça social, dignidade para os pobres e liberdade política na Coréia do Sul pelo menos desde a década de 70 (SUH, 1976; KIM, 1981; KIM, 1998). Há muitos pontos de contato com a TdL, o que a tornou assimilável e relevante para eles. A teologia Minjung aparece quando a Coréia estava se industrializando rapidamente e muitos pobres do campo foram atraídos para a cidade como mão-de-obra barata. Eles tinham baixos salários e viviam em condições miseráveis; eram explorados pelos industriais, que eram apoiados pelo regime político, que era apoiado pelo poder militar (AMALADOSS, s/d). Apesar da teologia Minjung não aceitar nem o marxismo nem algumas concepções cristãs e budistas que oferecem uma solução no "mundo do além", ela mantém uma visão escatológica em relação ao futuro. (AMALADOSS, s/d, p. 2) 
b) Segundo Peter Phan, as teólogas feministas da libertação são as mártires da libertação asiática (PHAN, 2012). A Teologia asiática feminista da libertação desenvolveu-se muito nos últimos anos, mas a realidade ainda é muito desfavorável às mulheres na Ásia. As mulheres pobres são as maiores vítimas de um sistema social patriarcal, machista e extremamente violento para com elas, sobretudo para com as meninas (PUI-LAN, 1994). As mulheres no campo às vezes trabalham 16 horas por dia para ganhar um "salário de fome". Elas sofrem não apenas discriminação e subordinação, mas passam também por situações de violência doméstica e humilhação na sociedade (MANAZAN, 1995). Alguns dos desafios que Mary John Manazan, junto com outros teólogos asiáticos, como M. Amaladoss (1997) enxergam para uma teologia asiática são: 1) elaborar uma teologia libertadora a partir das fontes cristãs; 2) realizar uma compreensão em profundidade das grandes religiões asiáticas para descobrir tanto seus elementos libertadores como suas forças opressivas, e como eles afetam as mulheres e os outros oprimidos; 3) entabular um processo de diálogo e comunhão de vida com as mulheres dessas religiões (MANAZAN, 1995, p. 32).

c) A Teologia da Luta e da Resistência nas Filipinas vem dos tempos de luta contra o regime do ditador Marcos, não tendo hoje a mesma expressão popular que antes. Ela não é uma teologia sobre a luta, mas da luta e na luta (AMALADOSS, s/d, p. 2), desenvolvida pelo povo pobre que está nela engajado. Trata-se de uma teologia popular, presente nas preces espontâneas e nas liturgias das comunidades de base (BATTUNG, 1988); no entanto, depois da ditadura vencida, os setores dominantes na sociedade mais uma vez traíram as expectativas das classes populares, o que provocou frustração e desmobilização, não obstante a continuidade dos processos de luta.

d) A Teologia da libertação Dalit é talvez a experiência teológica atual que mais impressiona e evoca semelhanças com a teologia latino-americana da libertação. Os Dalits são cerca de 240 milhões no mundo, só na Índia vivem cerca de 200 milhões (MASSEY, 2007, p. 107). Como casta mais baixa e marginalizada 
da sociedade indiana, vivem uma condição de condenados a uma permanente e estrutural humilhação (PHAN, 2012). Pensar a existência Dalit é fazer continuamente a experiência de viver sob o horizonte da servidão. Por isso, F. Wilfred considera que a teologia Dalit é a maior realização da teologia indiana, especialmente se considerada sob o ponto de vista sócio-político (WILFRED, 2007, p. 134). A teologia Dalit balançou as formas tradicionais de fazer teologia: primeiro porque, a exemplo da América Latina, há um movimento social de libertação Dalit que criou uma teologia da libertação Dalit, que a pensa e a reforça. Depois porque são os pobres mais excluídos que se movimentam e assumem a causa da sua autolibertação; terceiro, porque sendo em grande parte excluídos do saber, eles privilegiam a experiência (a práxis) e não as doutrinas teológicas; para os Dalits, a experiência é mais fundamental ainda do que a Bíblia e a tradição; quarto, porque através dessa experiência (teológica) de libertação, os Dalits estão alcançando autoidentidade e autoconfiança; quinto, porque sua teologia é da contracultura, é uma teologia do cativeiro, como a TdL na fase mais dura da ditadura (PHAN, 2012).

Esta teologia de libertação não se alimenta apenas dos conteúdos e material simbólico do Cristianismo; uma vez que a maioria dos Dalits não é cristã, ela precisa lançar mão, reconstruir e refazer os próprios recursos simbólicos da tradição Dalit, seus mitos, provérbios, cantos, festivais e rituais (WILFRED, 2007, p. 134). Este parece ser um traço marcante das teologias da libertação no contexto asiático: elas retiram e se abastecem com os recursos históricos, civilizacionais e culturais do seu próprio continente, no qual os cristãos são pequena minoria e precisam dialogar com seus vizinhos de outras religiões (WILFRED, 2008, p. 53). O teólogo do Sri Lanka, M. Amaladoss, vai em busca dos elementos libertários na literatura, nos mitos, nos escritos e na própria tradição do budismo, do islamismo, do confucionismo e das religiões cósmicas da India (AMALADOSS, s/d. p. 4-11). Para Peter Phan (2006, p. 18-25), uma hermenêutica teológica empregada no contexto asiático para ser libertadora precisa ser uma hermenêutica inter-religiosa, pós-colonial e baseada na vida do povo. 


\section{Teologia da Libertação como projeto transreligioso}

Como vimos nas páginas precedentes, mesmo tendo focado a atenção na teologia latino-americana, o projeto Teologia da Libertação foi levado adiante pelas diferentes teologias libertárias que nele se abrigam. As teologias da libertação estão presentes em muitas partes do mundo e foram assumidas por pessoas e grupos os mais diversos, que se apropriaram delas como ferramentas simbólicas para fazer valer sua necessidade ingente de expressão livre e de libertação das formas mais diversas de opressão: fome, exclusão social, preconceito racial, ódio de classe, violência étnica e de gênero, marginalização cultural, opressão religiosa, exploração da natureza e falta de harmonia com ela e os diferentes. Essas teologias da libertação conseguiram dar, em maior ou menor grau, um caráter internacional, ecumênico, interdisciplinar, inter-gênero, transnacional e até mesmo interreligioso, à sua atuação.

Diferentes teologias da libertação operam em “espaços” inter-religiosos ou já alcançaram formas de ação trans-religiosa. Marc Ellis, por exemplo, há tempos defende a existência de uma teologia da libertação dentro do judaísmo, e outros reportam de experiências libertadoras semelhantes no interior das religiões africanas, do hinduísmo, do islamismo e do budismo (ELLIS; MADURO, 1989). Como se dá na prática esse processo? Uma modalidade clara: os "agentes pedagógicos" provenientes das teologias da libertação atuam num contexto sóciocultural e religioso determinado, interagindo com universos simbólicos não cristãos ou não religiosos. Há um trânsito, um cruzamento de fronteiras entre universos simbólicos por parte desses agentes. Na grande maioria das vezes tratase de pessoas concretas, mas às vezes o que circulam são livros, testemunhos, relatos, histórias, imagens e material audiovisual vinculados a uma teologia da libertação específica.

Assim, dentro de outras religiões fora do Cristianismo elaboram-se discursos e práticas identificadas com a "plataforma” da teologia da libertação. Ou seja, não é apenas o conteúdo que as teologias da libertação defendem (a liberdade, a 
dignidade, o direito) que pode estar sendo assumido ou influenciando comunidades religiosas não cristãs, mesmo porque tal conteúdo existe nas outras religiões e não é exclusivo do Cristianismo. Trata-se de uma sensibilidade hermenêutica que está no fundo da ação política e discursiva das teologias da libertação. Ou, melhor ainda, trata-se de uma determinada forma de conjugar sensibilidade e conteúdo, "típica" das teologias da libertação, que pode estar sendo apropriada por outros universos religiosos, e mesmo por grupos sociais sem uma religiosidade determinada.

Paralelamente a esse processo, parece estar ocorrendo outro que é tão importante quanto o primeiro: Estão surgindo teologias libertárias fora das confessionalidades e do pertencimento religioso exclusivo. Isso quer dizer que estão surgindo teologias trans-religiosas ou não confessionais; ou mesmo não religiosas, ou seja, espiritualidades laicas. Todas elas, desde as fundamentalisticamente religiosas até as laicas, estão em constante enfrentamento e diálogo com uma "razão secular" (representada pelo Estado, mas não só), que pressiona e solicita da razão teológica (para além das fronteiras de uma religião particular) uma justificação para sua presença, para suas opções e suas formas de atuação no espaço público. O resultado desse processo está produzindo as diferentes versões e visões de teologia pública que hoje se elaboram no mundo (SANDAL, 2012; Von SINNER, 2009).9 Uma teologia pública libertadora, apesar de não ser uma Teologia da Libertação em senso estrito, pode estar ligada a ela por muitos aspectos: por um ideário de justiça social, uma pedagogia de formação para a cidadania e a corresponsabilidade social, pela biografia de seus proponentes e às vezes pelo próprio espaço e relevância conquistados historicamente pela Teologia da Libertação.

Ora, se as teologias da libertação se tornaram transnacionais, planetárias (VIGIL, 2011) e trans-religiosas, se influenciam teologias públicas e políticas laicas,

\footnotetext{
${ }^{9}$ No Brasil R. von SINNER (2009)e outros propuseram uma teologia da cidadania, como uma forma pertinente de teologia pública, levando adiante o projeto e a credibilidade da Teologia da Libertação. O debate sobre a necessidade, as implicações e as dificuldades de se articular uma tal teologia pública está apenas no começo (CADERNOS, 2006; SOARES; PASSOS, 2011).
} 
podemos dizer que estamos diante do processo de construção de um imaginário social global, ou mais especificamente, de um imaginário religioso global. Isso parece algo inédito na história das religiões.

\section{A Teologia da Libertação e o imaginário religioso mundial}

O conceito de imaginário social refere-se a um universo de significações que funda a identidade de um determinado grupo (CASTORIADIS, 1982). O imaginário social constitui uma constelação, um macro mapeamento do espaço social e político, através do qual percebemos, julgamos e agimos no mundo. Imaginários sociais "são modos enraizados que provêem os parâmetros mais gerais dentro dos quais as pessoas imaginam sua vida em comum” (STEGER, 2009, p. 12). Para C. Taylor, os imaginários sociais não são nem teorias nem ideologias, mas "panos de fundo" implícitos que tornam possível práticas em comum e dão a elas uma legitimação amplamente compartilhada (TAYLOR, 2010). Todo imaginário social consiste de uma série de narrativas, protótipos visuais, metáforas e quadros conceituais inter-relacionados e mutuamente dependentes. Mais do que colecionar imagens, o imaginário permite a imaginação; é ele que dá certos parâmetros para imaginar o que é possível e desejável. Para Steger,

\footnotetext{
O imaginário social oferece explicações de como "nós", os membros de uma comunidade particular, combinamos, como as coisas devem ser entre nós, que expectativas temos uns dos outros, bem como os valores e imagens mais profundos que fundamentam essas expectativas... (2009, p. 12).
}

Apesar de parecer um tanto intangíveis, os imaginários são bastante reais no sentido de possibilitar práticas comuns e laços comunitários profundos. É por causa de um imaginário compartilhado que podemos nos nomear e dizer: "nós brasileiros", "nós católicos"; "nós teólogas feministas".

Acontece que nos encontramos num acelerado processo de globalização. E globalização não se reduz ao seu componente econômico, não se trata apenas do 
aumento nos fluxos de bens e capitais entre as fronteiras dos estados nacionais. Globalização constitui um conjunto multidimensional de processos, nos quais imagens, histórias, metáforas, mitos, sons, símbolos e arranjos espaciais da globalidade são tão importantes como a dinâmica econômica e tecnológica. A globalização envolve tanto as macro-estruturas da sociedade como as microestruturas da personalidade, ela alcança o coração do "eu”, favorece a formação de novos pertencimentos e novas identidades. Fazemos a experiência subjetiva desses processos em termos de compressão do espaço e do tempo: o mundo encolheu. É nesse contexto em que o mundo se torna cada vez mais, objetiva e subjetivamente, um único "lugar" (R. Robertson), uma única "casa da humanidade”, que podemos falar da emergência de um imaginário social mundial. Sem dúvida, como as demais dinâmicas que movimentam os processos de globalização, também a emergência de tal imaginário mundial está perpassada por conflitos e espelha relações de poder; agentes sociais poderosos tentam influenciar o processo segundo seus interesses. $\mathrm{O}$ campo do imaginário também é um campo de luta política e pelo poder, onde se cruzam interesses de grupos sociais e ideologias (SERBENA, 2003). No entanto, segundo Steger,

O emergente imaginário global encontra sua articulação política concreta não apenas nas reivindicações ideológicas das elites sociais contemporâneas, que residem nos espaços privilegiados das nossas cidades globais. Ele também alimenta as esperanças, os desapontamentos e as demandas dos migrantes que atravessam as fronteiras nacionais em busca de sua fatia do sonho global. Assim, o global não é propriedade exclusiva de ninguém. Ele habita as classes, raças e gêneros, mas não pertence a nenhum deles. Nem pode ser definido separando o espaço geográfico em compartimentos estanques [...]. (STEGER, 2009, p. 13).

Podemos desde já afirmar: junto com um imaginário social global, surge também um imaginário religioso global. ${ }^{10} \mathrm{O}$ imaginário religioso global não está

\footnotetext{
${ }^{10}$ Poder-se-ia argumentar que a noção de imaginário religioso se sobrepõe ao conceito de campo religioso, elaborado por Bourdieu (1971). Porque não falar de um campo religioso global? De fato pode-se falar de um campo religioso globalizado, mas não se trata da mesma coisa. O conceito de campo religioso mantém certa pertinência, apesar das críticas que se lhe podem fazer, sobretudo o sobrepeso que dá aos conflitos pela hegemonia entre agentes religiosos e a pouca permeabilidade para processos originados em outros "campos". Mas por privilegiar as instituições religiosas e uma modalidade específica de interação, o conceito não capta bem os deslocamentos do religioso para outras esferas da vida social. Não inclui as imbricações dos processos de mudança econômica, política e cultural com a esfera religiosa, bem como dificulta visualizar outros aspectos da religião (simbologia, estética, profecia, espiritualidade) que não são necessariamente condicionados pelos conflitos em torno da hegemonia.
} 
num espaço geográfico específico, ele é um espaço (LASCH, 2012, p. 277); ele não está num local determinado, ele é um horizonte, um topos, presente e atuante, por causa da globalização cultural, em todos os contextos locais. A noção de imaginário religioso global tem a vantagem de visualizar a grande diversidade dos filões que compõem esse "mar", ou esse imenso "repertório" de tradições e correntes religiosas. O imaginário religioso global é uma parte significativa da cultura global que está sendo gestada (BOLI, 2005). Ele é constituído por aqueles relatos, imagens performáticas, motivos, intuições e ideias-força das religiões que, através de um processo não isento de conflitos e disputa se globalizaram e entraram para um quadro relativamente estável de representações. Como agentes políticopedagógicos que operam no espaço público da luta por direitos, todas as teologias da libertação tem imediatamente um caráter político, ainda que a dimensão política não expresse toda a sua natureza. Interessa-nos, por isso, perceber como as TdL estão contribuindo para influenciar, através da esfera pública, o imaginário religioso e o universo simbólico das religiões e das culturas. Steger (2009), por exemplo, analisa a presença forte - e negativa - da Al Qaeda nesse imaginário.

Vejamos rapidamente dois exemplos possíveis: o caso da teologia índia e da teologia Dalit. Na medida em que um teólogo índio do Panamá e um teólogo Dalit da India, ambos vindo da TdL, "resgatam" (na verdade constroem de novo) dentro de suas próprias culturas e tradições os temas, motivos, imagens, relatos e mitos que impulsionam uma atuação crítica e "libertadora", urgentemente necessária devido a um contexto de extrema violência e ameaça, eles estão recriando a Teologia da Libertação a partir dos referenciais de outro sistema simbólico e religioso. Mas também estão recriando seu "próprio” universo simbólico e religioso índio e Dalit desde um horizonte "novo". Este percurso kenótico e diacônico não deixa imune a própria Teologia da Libertação, como teologia de origem cristã e latino-americana. Ao imergir na cultura e na religião do "outro" e do "pobre" a Teologia da Libertação do teólogo passa por um processo de progressivo esvaziamento e reconversão: primeiro, ela abre mão de ser teologia confessional cristã; depois abre mão de ser teologia "da libertação"; afinal torna-se prática e 
espiritualidade libertadoras. Assim, a "libertação", como horizonte fundamental da sensibilidade e da ação, não é um elemento "invasor" ou uma "estratégia cristã" de colonização do outro - se for, sempre poderá ser expulsa e rejeitada. Mas esse horizonte e essa sensibilidade (da libertação) são digeridos e incorporados como algo próprio, que está presente e é alimentado pelas próprias raízes daquela cultura, religião ou sistema simbólico.

Esse percurso ao ser narrado e socializado pode marcar profundamente a experiência das pessoas, pode ser divulgado nas redes virtuais, pode ser relacionado com outros relatos, outros casos e outros contextos, pode eventualmente ser acompanhado, visibilizado pela mídia, tornar-se tema de livros e filmes. Pode afinal, não como caso isolado, mas como motivo, como imagem performática, passar a enriquecer um imaginário global acerca de como uma religião pode ser. Aliás, tal imaginário, mesmo em construção, já existe; às vezes um tanto unilateral, mas atuante, forte, motivador da imitação. Assim, enquanto proponentes de um horizonte ético e de uma sensibilidade espiritual libertadora, sempre encarnados em contextos singulares e vividos em lutas concretas, as teologias da libertação passam a povoar e a enriquecer o imaginário religioso global. Elas nem sempre precisam aparecer como tais (como teologias da libertação), desde que seu pressuposto ou elemento básico seja incorporado pelas pessoas (e religiões) com algo seu. Tendencialmente elas se tornariam um bem comum. A difusão global, a intensidade da experiência vivida e a persistência desses motivos na circulação global dos bens simbólicos, tudo pode reforçar a ação das teologias da libertação. Não há garantias, como sempre muitos riscos, mas surgem também algumas chances novas e inesperadas.

\section{Conclusão}

Como vimos nas páginas precedentes, as teologias da libertação são um projeto em aberto. Em termos de duração histórica a Teologia latino-americana da Libertação não viveu ainda o tempo de uma biografia humana. É jovem e recente, boa parte dos seus mentores iniciais ainda está aí. No entanto, nos últimos 45 anos 
esse movimento fez muita coisa: levou a teoria acadêmica a mudar sua compreensão do fenômeno religioso, mudou a cara da própria religião, revelou formas de Cristianismo que não se julgavam possíveis, depois de séculos de neoescolática, pietismo, ultramontanismo, burocracia e pactos com o poder. Löwy (2000) corrigiu Marx, Weber e até Bourdieu, que não acreditavam ser possível rimar devoção com revolução. Pela capacidade de irradiação que o movimento tem demonstrado em contextos diferentes e entre públicos diversos, esse processo de recriação está longe de acabar.

A atual fase avançada de aproximação e recomposição de fronteiras entre sistemas simbólicos coloca desafios inusitados às teologias da libertação. Não apenas às TdL, mas a todas as formas de espiritualidade libertária que não queiram ser reduzidas a um gueto. No seu processo de difusão global, a cultura de mercado constrói imaginários que reduzem religião a estética, limitam espiritualidade a emoção e espetáculo. Tudo para o desfrute privado dos indivíduos. Sem desconsiderar o estético e o prazer na existência, o desafio para as teologias da libertação será manter práticas pessoais e coletivas de luta, fundadas numa hermenêutica inteligente da fé, contra formas novas e velhas de injustiça e sofrimento. Por isso parece tão importante construir imaginários que associem experiência religiosa com práticas políticas emancipatórias e bio-sustentáveis.

Para Castoriadis, o imaginário não é um acervo, um depósito, uma informação a ser arquivada, mas uma fonte (AUGRAS, 2009, p. 235). Além disso, o imaginário opera não por racionalização ou dedução, mas por imitação. Temos então o direito de esperar que o imaginário global em torno da Teologia da Libertação opere como uma fonte. Uma fonte de imagens, relatos, exemplos e provocações subversivas para as religiões conformistas e burocratizadas; uma fonte de desejos de justiça e igualdade encarnados na vida de pessoas de fé que lutam contra regimes políticos opressores; uma fonte de memórias perigosas que assaltam os sistemas idolátricos; mas também uma fonte de inspiração e sabedoria para viver bem (sumak kawsai), em harmonia com o diferente e em paz com a mãe terra. 


\section{REFERÊNCIAS}

ACKERMANN, D. Feminist Liberation Theology. Journal of Theology for Southern Africa, Cape Town, n. 62, p.14-28, 1988. Disponível em:

<http://www.womenpriests.org/theology/ackermann.asp>. Acesso em: 10 out. 2013.

AMALADOSS, M. Liberation Theologies from Asia. s/d. Paper-resumo. Disponível em: <http://www.idcrdialogue.com/seminars.php>. Acesso em: 10 out. 2013.

AMALADOSS, M. Life in Freedom: Liberation Theologies from Asia. Maryknoll: Orbis Books, 1997.

APPIAH-KUBI, K.; TORRES, S. (orgs.) African Theology en route: papers from the Pan African Conference of Third World Theologians. Dec. 1977, Accra. New York: Orbis, 1979.

AQUINO, M. P. Nuestro Clamor por la Vida: Teologia latinoamericana desde la perspectiva de la mujer. San Jose, Costa Rica: DEI, 1992.

ASETT (Org.). Pelos muitos caminhos de Deus: desafios do pluralismo religioso à Teologia da Libertação. Goiânia: Rede, 2003.

ASSMANN, H. Por uma teologia humanamente saudável. Em: SUSIN, L. C. (org.) O mar se abriu. Trinta anos de teologia na América Latina. São Paulo: Loyola, 2000. p. 115-130.

ASSMANN, H. Teologia da Solidariedade e da Cidadania: continuando a Teologia da Libertação. Notas - Jornal de Ciência da Religião, São Bernardo do Campo, v. 1, n. 2, p. 29, jan/fev, 1994 .

ATABAQUE-ASETT. Teologia afro-americana. São Paulo: Paulus, 1997.

AUGRAS, M. Imaginário da magia: magia do Imaginário. Petrópolis: Vozes, 2009.

BATTUNG, M.R. et al. Religion and Society: Towards a Theology of Struggle. Manila: Fides, 1988.

BEOZZO, J. O. Nota sobre os participantes da celebração do Pacto das

Catacumbas. 2009. Disponível em: <http://www.ccpg.puc-

rio.br/nucleodememoria/dhc/textos/beozzocatacumbas.pdf>. Acesso em: 10 out. 2013.

BETTAZZI, L. Das Zweite Vatikanum: Neustart und Aufbruch. Würzburg: Echter, 2012.

BOFF, L. (org). A Teologia da Libertação. Balanços e Perspectivas. São Paulo: Ática, 1996. 
BOFF, L. Dimensão política e teológica da ecologia. CEPIS, São Paulo, 74p. (mimeogr.), 1992a.

BOFF, L. Ecologia, mundialização e espiritualidade. São Paulo: Ática, 1993 a.

BOFF, L. Natureza e sagrado: a dimensão espiritual da consciência ecológica. In: UNGER, N. M. (Org.). Fundamentos filosóficos do pensamento ecológico. São Paulo: Loyola, 1992b. p. 75-80.

BOFF, L. Por uma ecologia da libertação. Ecologia e desenvolvimento, Rio de Janeiro, v. 1 , n. 12 , p. 61-63, $1992 \mathrm{c}$.

BOFF, L.; Frei BETTO. Mística e espiritualidade. São Paulo: CEPIS/Movimento Fé e Política, $1993 b$.

BOLI, J. Contemporary Developments in World Culture. International Journal of Comparative Sociology, London: Sage Publications, n. 46, v. 5-6, p. 383-404, 2005.

BOURDIEU, P. Economia das trocas simbólicas. São Paulo: Perspectiva, 1971.

BRIGHENTI, Agenor; HERMANO, Rosario (Org.). A Teologia da Libertação em prospectiva. São Paulo: Paulinas, 2013.

BUTHELEZI, M.; BIKO, S.; PITYANE, N. Essays on Black theology. Cape Town: Black Theology Project, University Christian Movement, 1972.

CASTORIADIS, C. A Instituição Imaginária da Sociedade. Rio de Janeiro: Paz e Terra, 1982.

CHAKKALAKAL, P. Asian Women Reshaping Theology: Challenges and Hopes. Feminist Theology - The Journal of the Britain \& Ireland School , London, v. 9, n. 27, p. 21-35, 2001.

COMBLIN, J. J. Trinta anos de teologia latino-americana, em SUSIN, L.C. (Org.). O mar se abriu. Trinta anos de teologia na América Latina. São Paulo: Soter-Loyola, 2000. p. 179-192.

COMISSÃO PASTORAL DA TERRA CPT (org.) Conquistar a terra, reconstruir a vida. Petrópolis: Vozes, 1985.

CONCILIUM, Petrópolis, v. 13, n. 124(4), p. 377-506, 1977.

CONE, J. H. A Black Theology of Liberation. New York: Orbis, 1980. 
CONFEDERAÇÃO EVANGÉLICA DO BRASIL. Setor de Responsabilidade Social (Org.) Cristo e o processo revolucionário brasileiro. A Conferência do Nordeste. Rio de Janeiro: Editora Loqui, s/d.

DICKSON, K.; ELLINGWORTH, P. Biblical Revelation and African Beliefs. Londres: Lutterworth Press, 1969.

DUSSEL, E. Teología de la liberación y ética. Caminos de liberación Latinoamericana, II. Buenos Aires: Latinoamérica Libros, 1972.

DUSSEL, E. Teología de la Liberación. Panorama de su desarrollo. México: Potrerillos Editores, 1995.

ELLIS, M.; MADURO, O. (Org.) The future of Liberation Theology: Essays in Honor of Gustavo Gutiérrez. Maryknoll: Orbis, 1989.

FIORENZA, E.S. Feminist Theology as a critical Theology of Liberation.Theological Studies, Milwaukee, v. 36, n. 4, p. 605-626, Dec. 1975.

FÜSSEL, K.; RAMMINGER, M. (orgs.) Zwischen Medellín und Paris. 1968 und die Theologie. Luzern/Münster: Exodus-ITP Kompass, 2009.

GEBARA, I. Teologia Feminista e a crítica da razão religiosa patriarcal: entrevista com Ivone Gebara. Revista Estudos Feministas, Florianópolis, v. 14, n. 1, p. 294-304, janabr 2006.

GIACCARIA, B. Indios fazem teologia. Primeiro Encontro Latino-Americano de Teologia Indígena, Cidade do México, 17 a 23/09/90. Disponível em:

<http://www.faje.edu.br/periodicos/index.php/perspectiva/article/viewFile/1344/1737>. Acesso em 10 out. 2010.

GUTIÉRREZ, G. Teología de la liberación. Perspectivas. Salamanca: Sígueme, 1971.

IGREJA CATÓLICA. Congregação para a Doutrina da Fé. Instrução sobre a liberdade cristã e a libertação. São Paulo: Paulinas, 1986.

IGREJA CATÓLICA. Sagrada Congregação para a Doutrina da Fé. Instrução sobre alguns aspectos da “teologia da libertação". Petrópolis: Vozes, 1984.

JAUME, B. Cristãos para o Socialismo. Agenda Latino-Americana 2oog. Disponível em:

<http://www.servicioskoinonia.org/agenda/archivo/portugues/obra.php?ncodigo=141>. Acesso em : 10 out. 2013.

JORNADAS DE FE CRISTIANA Y CAMBIO SOCIAL EN AMERICA LATINA, 20, 1972, San Lonrezo de El Escorial, Madrid. Fé cristã e transformação social na América Latina encontro de El Escorial, 1972. Petrópolis: Vozes, 1977. 
KIM, E. Minjung Theology in Korea. A Critique from a Reformed Theological Perspective. Japan Christian Review, Nagoya, v. 64, p. 53-65, 1998. Disponível em: <http://nirc.nanzan-u.ac.jp/nfile/4182>. Acesso em: 10 out. 2013.

KIM, Y. B. (org). Minjung theology. Singapore: The Christian Conference of Asia, 1981.

LASCH, S. Deforming the Figure: Topology and the Social Imaginary. Theory, Culture \& Society, Nottingham, v. 29, n.4-5, p. 261-287, 2012.

LÖWY, M. A Guerra dos deuses. Religião e política na América Latina. Petrópolis:

Vozes-Clacso, 2000.

LÖWY, M. A Teologia da Libertação: Leonardo Boff e Frei Betto. Adital. 23 out. 2008. Disponível em: < http://site.adital.com.br/site/noticia.php?lang=PT\&cod=35648>. Acesso em: 12 set. 2013.

LÖWY, M. O catolicismo latino-americano radicalizado. Estudos Avançados, São Paulo, IEA-USP, v. 3, n. 5, p. 50-59, jan-abr 1989.

MAGALHÃES, Thamiris. Congresso Continental de Teologia celebra os 50 anos do Concílio Vaticano II e os 40 anos da Teologia da Libertação. IHU Unisinos, o8 out. 2012. Disponível em: <http://www.ihu.unisinos.br/noticias/514362-inicia-o-congressocontinental-de-teologia-com-jon-sobrino>. Acesso em: 14 out. 2013.

MANANZAN, M.J. Feminist Theology in Asia: A Ten Years' Overview. Feminist Theology, Londres-Dehli, n. 4, p. 21-32, Sept. 1995.

MASSEY, J. God, ethnic cultural traditions and globalization. In: ALTHAUS-REID, M., PETRELLA, I.; SUSIN, L.C. (Org.) Another possible world. Londres: SCM Press, 2007.

McDONAGH, E. "The Challenge of Liberation Theology". In: LANE, D.A. (Org). Liberation Theology: An Irish Dialogue. Dublin: Gill and Mamillan, 1977.

MOREIRA, A. da S. Contribuições da Teologia da Libertação para os movimentos sociais.

Caminhos, Goiânia, v. 10, n. 2, p. 37-55, jul./dez. 2012.

MOREIRA, A. da S. Das endlose Jahr. 1968 in Brasilien. In: FÜSSEL, K.; RAMMINGER, M. (Org.) Zwischen Medellín und Paris. 1968 und die Theologie. Luzern/Münster: Exodus-ITP Kompass, 2009. p. 142-161.

MOREIRA, A. da S. O dom da terra. Leitura teológica dos conflitos agrários no Brasil. Bragança Pta: CPT-EDUSF, 2006.

MOREIRA, A. da S. Un nuevo Pentecostés: el Concilio Vaticano II entre la memoria y el olvido. Horizonte, Belo Horizonte, v. 9, n. 24, p. 1267-1279, out./dez. 2011. 
MUZOREWA, G. H. African Liberation Theology. Journal of Black Theology in South Africa, Durban, v. 3 n. 2, p. 52-70, nov. 1989. Disponível em: <http://www.disa.ukzn.ac.za/webpages/DC/BtNov89.1015.2296.003.002.Nov1989.8/BtN ov89.1015.2296.003.002.Nov1989.8.pdf>. Acesso em: 15 out. 2013.

NTHAMBURI, Z. African Theology as a Theology of Liberation. African Ecclesial Review (AFER), Kampala, n. 22, p. 232-239, 1980.

ODUYOYE, M. A. Introducing African Women’s Theology. Sheffield: SUP, 2001.

ORTIZ, Renato. Mundialização e cultura. São Paulo: Brasiliense, 1994.

ORTIZ, Renato. Mundialização, modernidade, pós-modernidade. Entrevista com Renato Ortiz por S. F. Marzochi. Cências Sociais Unisinos, São Leopoldo, v. 43, n. 1, p.103-105, janeiro/abril 2007.

PHAN, P. C. Teologia da Libertação e as igrejas asiáticas: uma verdadeira sinfonia. Conferência durante o Congresso Continental de Teologia da Libertação, Unisinos, 10 out. 21012. Disponível em: <http://www.ustream.tv/recorded/26047472>. Acesso em 15 out. 2013.

PHAN, P. C. Whose Experiences? Whose Interpretations? Contribution of Asian Theologies to Theological Epistemology. Irish Theological Quarterly, Dublin, n.71, p. 5-28, 2006.

POLETTO, I.; CANUTO, A. Nas pegadas do povo da terra. 25 anos da Comissão Pastoral da Terra. São Paulo: Loyola-CPT, 2002.

PUI-LAN, K. The Emergence of Asian Feminist Consciousness on Culture and Theology', in: POBEE, J. (Org.) Culture, Women and Theology. Delhi:ISPCK, 1994. p 73.

QUEIRUGA, A. T. O diálogo das religiões. São Paulo, Paulus, 1996.

RIBEIRO, Claudio de Oliveira. A Teologia da Libertação Morreu? Reino de Deus e espiritualidade hoje. São Paulo: Fonte Editorial, 2010.

RIBEIRO, Claudio de Oliveira. A Teologia latino-americana diante do pluralismo religioso. Horizonte, Belo Horizonte, v. 11. n. 32, p. 1436-1460, out./dez. 2013.

RUETHER, R. R. The Development of Feminist Theology: Becoming Increasingly Global and Interfaith. Feminist Theology, London, v. 20, n. 3, p. 185-189, 2012.

RUETHER, R.R. Feminist Theologies in Latin America. Feminist Theology, London, n. 9, p.18-32, 2000.

SANDAL, N. A. The Clash of Public Theologies? Rethinking the Concept of Religion in Global Politics. Alternatives: Global, Local, Political, New York, v.37, n. 1, p. 66-83, 2012.

SCHERER-WARREN, I. Redes de movimentos sociais. São Paulo: Loyola, 1996. 
SEGATO, R. "Liberation Theology”. In: SCHOLTE, J.A.; ROBERTSON, R. (Org.)

Enciclopedia of Globalization. New York: Routledge, 2006. p. 629-632.

SEGUNDO, Juan Luis. Liberación de la teología. Buenos Aires: Lohlé, 1973.

SERBENA, C.A. Imaginário, Ideologia e Representação Social. Cadernos de Pesquisa

Interdisciplinar em Ciências Humanas, Florianópolis, v. 4, n. 52, p. 1-12, dez. 2003. Disponível em:

<https://periodicos.ufsc.br/index.php/cadernosdepesquisa/article/view/1944>. Acesso em: 15 out. 2013 .

SINNER, R. (Org.) Teologia Publica em debate. São Leopoldo: Sinodal-EST, 2011.

SINNER, R. Da Teologia da Libertação para uma teologia da cidadania como teologia pública. Comunicações do III Fórum Mundial de Teologia e Libertação, Belém, 2009. Disponível em:

<http://www.academia.edu/2357598/Da_Teologia_da_Libertacao_para_uma_teologia_ da_cidadania_como_teologia_publica $>$. Acesso em: 18 out.2013.

SOARES, A. M. L.; PASSOS, J. D. (Org.). Teologia pública: reflexões sobre uma área de conhecimento e sua cidadania acadêmica. São Paulo: Paulinas, 2011.

STEGER, M. Globalisation and Social Imaginaries: The Changing Ideological Landscape of the Twenty-First Century. Journal of Critical Globalisation Studies, Londres, n. 1, p. 9-10, 2009.

SUESS, P. Rückflug. Medellín 40 Jahre später. In: FÜSSEL, K.; RAMMINGER, M. (Org.) Zwischen Medellín und Paris. 1968 und die Theologie. Luzern-Münster: Exodus-ITP, 2009.

SUH, N.-D. Theology at turning point. Seoul: Korean Theological Study Institute, 1976.

SUSIN, L. C. (org.) O mar se abriu. Trinta anos de teologia na América Latina. São Paulo: Loyola-Soter, 2000.

SUSIN, L.C. Por que um Fórum Mundial de Teologia e Libertação. IHU-Online, 09 jan. 2009, Disponível em: <http://www.ihu.unisinos.br/noticias/noticias-anteriores/19125-por-queum-forum-mundial-de-teologia-e-libertacao>. Acesso em: 15 set. 2013.

TAYLOR, C. Imaginarios Sociais Modernos. Lisboa: Texto\&Grafia, 2010.

TEOLOGIA PÚBLICA. Cadernos IHU em formação, São Leopoldo, v. 2, n. 8, 2006. Instituto Humanitas Unisinos. Disponível em: <

http://www.ihu.unisinos.br/images/stories/cadernos/formacao/oo8cadernosihuemforma cao.pdf >. Acesso em: 10 out. 2010.

TOMITA, L.; BARROS, M. e VIGIL, J. M. (Org.). Teologia pluralista libertadora intercontinental. São Paulo: Paulinas, 2008. 
TOMITA, L.; BARROS, M.; VILGIL, J. M. (Org.). Pluralismo e Libertação: por uma teologia latino-americana pluralista a partir da fé cristã. São Paulo: Loyola, 2005.

TOMITA, L.; BARROS, M.; VILGIL, J. M. (Org.). Teologia latino-americana pluralista da libertação. São Paulo: Paulinas, 2006.

TORRES, S.; EAGLESON, J. (Org.) Theology in the Americas. New York: Orbis Books, 1976.

TORRES, S.; FABELLA, V. The Emergent Gospel. Theology from the Underside of History: Papers from the Ecumenical Dialogue of Third World Theologians, Dar Es Salaam, Aug. 5-12, 1976. New York: Orbis, 1978.

UKPONG, J. S. Current Theology. The Emergence of African Theologies. Theological Studies, Milwaukee, n. 45, p. 501-536, 1984.

VENTURA, Z. C. 1968, o ano que não terminou. Rio de Janeiro: Nova Fronteira, 1985.

VIGIL, J. M. Por uma teologia planetária. São Paulo: Paulinas, 2011.

VIGIL, J.M. Teologia do pluralismo religioso. São Paulo: Paulus, 2006.

WAGUA, A. Desde el silencio índio. Poemas. Ustupu, Panamá: Fé y Alegría, 1992.

WILFRED, F. Indian theologies: Retrospects and perspectives. In: ALTHAUS-REID, M.; PETRELLA, I.; SUSIN, L.C. (Org.) Another possible world. Londres: SCM Press, 2007.

WILFRED, F. Margins: site of Asian Theologies. Dehli: ISPCK, 2008.

WILFRED, F. Theologie vom Rand der Gesellschaft. Eine indische Vision. Freiburg: Herder, 2006. 